\title{
2- Isopentenyladenine in the induction of direct somatic embryogenesis capacity of Coffea arabica $\mathrm{L}$.
}

\section{Ivanilda dos Santos Alves ${ }^{1}$ Valéria Cristina Barbosa Carmazini ${ }^{1}$ Cosme Damião dos $\operatorname{Santos}^{2 \dagger}$ Julieta Andrea Silva de Almeida ${ }^{*}$}

${ }^{1}$ Centro de Café ‘Alcides Carvalho’, Instituto Agronômico de Campinas (IAC), 13020-902, Campinas, SP, Brasil. E-mail: julietasa@iac.sp.gov.br. ${ }^{*}$ Corresponding author.

${ }^{2}$ Escola Técnica Conselheiro Antônio Prado (ETECAP), Centro Paula Souza, Campinas, SP, Brasil. In memorium.

ABSTRACT: This study evaluated the effect of different concentrations of 2-isopentenyladenine (2-iP) on the direct somatic embryogenesis capacity of the Mundo Novo cultivar of Coffea arabica. Leaf explants were cultivated with half the MS salt concentration and the addition of sucrose $\left(20 \mathrm{gL}^{-1}\right)$ and $2-i P(0 ; 2.5 ; 5 ; 7.5$ and $10 \mu \mathrm{M})$. The 2-iP doses of 7.5 and $10 \mu \mathrm{M}$ produced the greatest responses with respect to the percentage of explants with embryogenic structures and the size of the embryogenic structures. However, the greatest production of somatic embryos occurred on the explants treated with $10 \mu \mathrm{M}$ of $2-i P$, followed by $7.5 \mu \mathrm{M}$, whereas their production was absent or reduced with 0 and $5 \mu M$, respectively.

Key words: Cultivar Mundo Novo, 2-iP, somatic embryos, embryogenic structures.

2- Isopenteniladenina na capacidade de indução da embriogênese somática direta de Coffea arabica $\mathrm{L}$.

RESUMO: Este estudo avaliou o efeito de diferentes concentrações de 2-isopentalinadenina (2-iP) na capacidade de embriogênese somática direta da cultivar Mundo Novo de Coffea arabica. Explantes foliares foram cultivados em meio com metade da concentração de sais de MS e adição de sacarose $\left(20 \mathrm{~g} \mathrm{~L}^{-}\right)$e de 2-iP $(0 ; 2,5 ; 5 ; 7,5$ e $10 \mu \mathrm{M})$. Os tratamentos com 7,5 e $10 \mu \mathrm{M}$ de 2-iP induziram respostas mais elevadas de porcentagem de explantes com estruturas embriogênicas e de tamanho de estrutura embriogênica. Porém, os explantes tratados $10 \mu M$ de 2-iP tiveram maior produção de embriões somáticos, seguido de 7,5 $\mathrm{M}$, enquanto nos tratamentos controle e com $5 \mu M$, as respostas foram respectivamente de ausência e de baixa formação destes.

Palavras chave: Cultivar Mundo Novo, 2-iP, embriões somáticos, estrutura embriogênica.

In Brazil the culture of coffee is mainly based on planting Coffea arabica cultivars and its hybrids. However these hybrids must be vegetatively multiplied in order to preserve their differentiated characteristics (NONGDAM, 2016) which can be done by somatic embryogenesis.

Somatic embryogenesis produces somatic embryos as from haploid or diploid cells without fusion of the gametes (von ARNOLD et al., 2002). This process can occur by direct or indirect via. The indirect via occurs in two phases, first calogenesis followed by the initiation of somatic embryos as from callus. Direct somatic embryogenesis occurs in a single step, without calogenesis, the embryos forming directly from determined cells and preembryogenic parts situated in regions on the explant edges (WILLIAMS \& MAHESWARAN, 1986).
C. arabica genotypes can be multiplied by indirect (ALMEIDA et al., 2008) or direct (ALMEIDA \& SILVAROLLA, 2009) somatic embryogenesis, or by both. However, the indirect route is usually used for the multiplication of the species C. arabica, whereas the direct route is inefficient, taking a long time and producing few embryos. NIC-CAN et al. (2015) showed that the inefficiency of the direct route in $C$. arabica is associated with inhibitory substances present in the leaf explant tissues, which prevents the formation of embryos. Despite this the direct route is still of greater advantage than the indirect route, since it occurs in a single phase allowing for a reduction in consumables and manual labor, such that studies aiming to increase its efficiency are relevant.

Of the plant growth regulators, auxins and cytokinins influence the somatic embryogenesis 
response in the majority of species (SHARMA, 2017). However, in C. arabica explants direct somatic embryogenesis is normally unleashed by the presence of a cytokinin without the need for auxin (YASUDA et al., 1985). The 6-Benzyladenine is the cytokinin most frequently used to unleash the direct route in this species (YASUDA et al., 1985, ALMEIDA \& SILVAROLLA, 2009). The literature includes a few reports of the application of 2-iP for the direct route in C. arabica (GATICA-ARIAS et al., 2007; KAHIA et al., 2016). Thus the objective of this study was to verify the effect of different concentrations of the cytokinin 2-iP on direct somatic embryogenesis in leaf explants of the Mundo Novo cultivar of C. arabica.

Expanded leaves, taken from up to the third pair of branches of adult plants of the $C$. arabica cultivar Mundo Novo, and maintained in an experimental area of the Agronomic Institute, Campinas, Brazil, were used. After picking them, the leaves were washed in a detergent solution to remove dust, immersed in a $2 \%$ sodium hypochlorite solution for 25 minutes and then rinsed 3 times in autoclaved distilled water. They were then maintained in a moist chamber for 24 hours and then disinfested again as previously described. Rectangular $1.5 \times 2.0 \mathrm{~cm}$ explants were obtained from the disinfested leaves. The explants obtained were inoculated with the adaxial face in contact with the surface of the culture medium, using $30 \mathrm{~mL}$ volumes of the culture medium contained in $200 \mathrm{~mL}$ transparent glass flasks, maintained in the absence of light at temperature of $25^{\circ} \mathrm{C}$.
The culture medium used to induce direct somatic embryogenesis consisted of half the concentration of MS salts (MURASHIGE \& SKOOG, 1962), with the addition of $20 \mathrm{gL}^{-1}$ sucrose and the following concentrations of 2-iP: $0 ; 2.5 ; 5$; 7.5 and $10 \mu \mathrm{M}$. The same culture medium was used to germinate the embryos without the addition of plant growth regulators, maintained for 16 hours in the light, illuminated by cool white fluorescent lamps of 4.000 lux of light intensity. The $\mathrm{pH}$ of the culture media was adjusted to 5.8 , jellified with $5 \mathrm{gL}^{-1}$ of agar and it was autoclaved at $121^{\circ} \mathrm{C}$ and $1.5 \mathrm{~atm}$ for twenty minutes. The experiment was set up in an entirely randomized design, each treatment consisted of fifteen replicates, using one explant in each. Treatments were evaluated monthly with respect to the number of explants showing the formation of embryogenic structures, estimate of the size of the embryogenic structures and the number of somatic embryos formed. Embryogenic structure corresponds to a mass of tissue developed on the foliar explant edges. Size of the embryogenic structure was estimated indirectly with the aid of a ruler. The data were submitted to regression using the SAS (Statistical Analysis System, version 8.3).

Explants from the cultivar Mundo Novo showed the capacity for direct somatic embryogenesis which was unleashed in the majority of the treatments with 2-iP, forming embryogenic structures (Figure 1A) and somatic embryos (Figure 1B) on the explant edges in a single culture

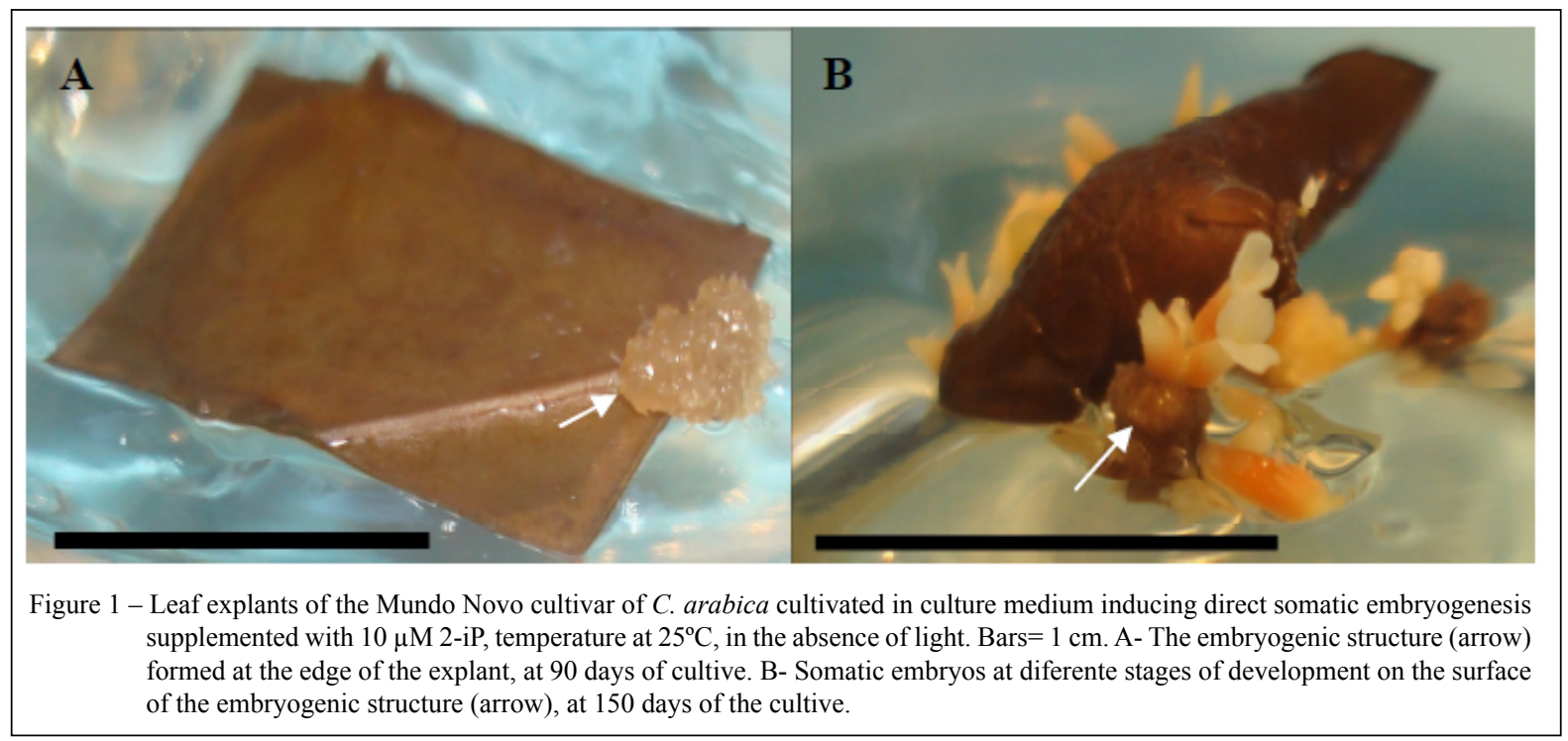

Ciência Rural, v.48, n.11, 2018. 
medium, and they were formed on both green and oxidized explants.

Explants formed embryogenic structures in all the treatments with 2-iP, except for the control (Figure 2A). Using a dose of $2.5 \mu \mathrm{M}$ the number of explants forming embryogenic structures was close to $20 \%$ during the experiment, and this response practically doubled in the treatment with $5 \mu \mathrm{M}$, reaching about $40 \%$ by the end of the experiment. Conversely, treating with 7.5 and $10 \mu \mathrm{M}$ caused a significant increase in responses of explants, almost $80 \%$ forming embryogenic structures as from 30 days after starting the experiment. Besides, it was shown that the size of these structures also varied according to the 2-iP dose (Figure 2B). The treatments with 2.5 and $5 \mu \mathrm{M}$ resulted in structures of 0.1 and $0.5 \mathrm{~mm}$, respectively, in all the evaluations, whereas after 30 days, the structures resulting from the treatments with 7.5 and $10 \mu \mathrm{M}$ were of $0.5 \mathrm{~mm}$, reaching 0.9 and $1 \mathrm{~mm}$, respectively, at the end of the

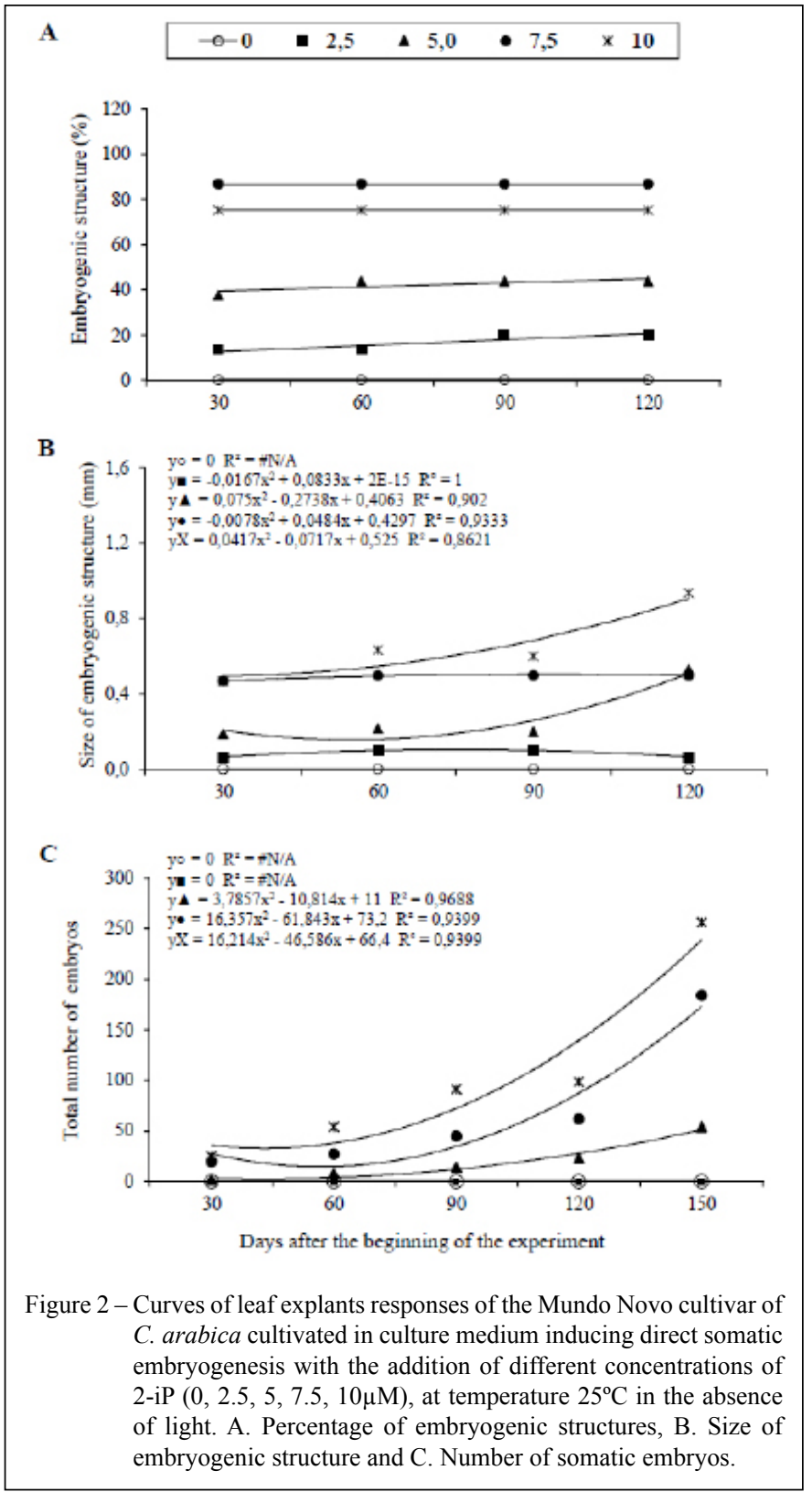

Ciência Rural, v.48, n.11, 2018. 
experiment. It should be pointed out that; although, the embryogenic structures were small and produced in small numbers on the edges of the explants, they were relevant since they could form embryos on their surfaces, which contributed to the efficiency of the direct route with $C$. arabica explants.

With respect to embryo formation, it can be seen that this also varied according to the 2-iP concentration (Figure $2 \mathrm{C}$ ). In the treatments with 0 and $2.5 \mu \mathrm{M}$ the explants did not form embryos and production was low with $5 \mu \mathrm{M}$, reaching a total of 40 at the end of the evaluations. The treatment with $7.5 \mu \mathrm{M}$ caused a gradual increase in embryo production, starting with 20 in the first 30 days and reaching 62 at the end of the experiment. Conversely, the greatest embryo production was reported with $10 \mu \mathrm{M}$, forming 22 after 30 days of cultivation, which increased to 60 in the second evaluation and reached over 100 after 90 days.

Results indicated that the explant cells were more sensitive to 2-iP concentrations equal or greater to $5 \mu \mathrm{M}$ with respect to embryo formation. Thus the efficiency of the direct route with $C$. arabica explants as a response to the treatment with $10 \mu \mathrm{M}$ of 2 -iP showed that this was the more adequate condition, with a greater production of embryos than with the lower doses. It was also observed that for the majority of treatments, each monthly evaluation carried out showed the formation of new embryos, indicating that the embryogenesis competence acquired by the cells at the start of the treatment was preserved for a long time. In addition, the responses of the absence or limited embryo formation could also be related to the possible presence of substances that inhibit somatic embryogenesis in leaf explants of this species, according to the results of NIC CAM et al. (2015), suggesting that higher 2-iP concentrations might interfere with the action of these inhibitors, favoring an increase in the production of somatic embryos and the formation of larger embryogenic structures. According to HILL \& SCHALLER (2013), explants that accumulate high endogenous levels of cytokinins tend to be more responsive to treatment with exogenous cytokinins. Natural differences in the ability to synthesize and respond to cytokinins appear to have a significant role in the capacity for in vitro regeneration. Finally the results obtained reinforce the prominent influence of the cytokinins in unleashing the direct route in C. arabica leaf explants.

\section{ACKNOWLEDGEMENTS}

We acknowledge the Consórcio de Pesquisa Café (Code of the Action Plan: 02.09.20.101.00.05) for scholarships and the Fundação de Amparo à Pesquisa do Estado de São Paulo (FAPESP), (Process: 11/10090-1).

\section{DECLARATION OF CONFLICTING INTERESTS}

The authors declared no potential conflicts of interest with respect to the research, authorship, and/or publication of this article.

\section{AUTHORS' CONTRIBUTIONS}

All authors contributed equally for the conception and writing of the manuscript. All authors critically revised the manuscript and approved of the final version.

\section{REFERENCES}

ALMEIDA, J.A.S.; SILVAROLLA, M.B. Induction of somatic embryos of Coffea arabica genotypes by 6-Benzyladenine. International Journal of Plant Developmental Biology, v.3, n.1, p.5-8, 2009. Available from: $<\mathrm{http}: / / \mathrm{www}$.globalsciencebooks. info/Online/GSBOnline/images/0906/IJPDB_3(1)/IJPDB 3(1)59o.pdf>. Accessed: Apr. 20, 2013.

ALMEIDA, J.A.S. et al. Embriogênese somática em genótipos de Coffea arabica L. Coffee Science, v.3, n.2, p.143-151, 2008. Available from: <http://www.coffeescience.ufla.br/index.php/ Coffeescience/article/view/85/173>. Accessed: Apr. 18, 2013.

GATICA-ARIAS, A.M. et al. Comparison of three in vitro protocols for direct somatic embryogenesis and plant regeneration of Coffea arabica L. cvs. Caturra and Catuaí. Agronomia Costarricense, v.31, n.1, p.85-94, 2007. Available from: <http:/www.mag.go.cr/ rev_agr/v31n01_085.pdf>. Accessed: Jun 04, 2018.

KAHIA, J. et al. High-frequency direct somatic embryogenesis and plantlet regeneration from leaves derived from in vitro germinated seedlings of a Coffea arabica hybrid cultivar. HortScience, v.51, p.1148-1152, 2016. Available from: doi:10.21273/ HORTSCI10771-16. Accessed: Jun. 13, 2017.

HILL, K., SCHALLER, G.E. Enhancing plant regeneration in tissue culture: A molecular approach through manipulation of cytokinin sensitivity. Plant Signaling Behavior, v.8, n.10, e25709, 2013. Available from: <http://dx.doi.org/10.4161/psb.25709>. Accessed: Dec. 9, 2017.

MURASHIGE, T.; SKOOG, F. A revised medium for rapid growth and bioassays with tobacco tissue cultures. Physiologia Plantarum, v.15, n.3, p.473-497, 1962. Available from: $<$ https://doi. org/10.1111/j.1399-3054.1962.tb08052.x>. Accessed: Dec. 13, 2017.

NIC-CAN, G.I. et al. Somatic embryogenesis: Identified factors that lead to embryogenic repression. A case of species of the same genus. Plos One, v.10, n.6..e0126414, 2015. Available from: $<$ https:// journals.plos.org/plosone/article?id=10.1371/journal.pone.0126414>. doi: 10.1371/jornal:pone.0126414. Accessed: Dec. 14, 2017.

NONGDAM, P. Development of synthetic seed technology in plants and its applications: A Review. International Journal Current Science, v.19, n.4, p.86-101, 2016. Available from: $<$ http://www.currentsciencejournal.info/issuespdf/Nongdam.pdf $>$. Accessed: Sep. 09, 2017. 
SHARMA, H. Role of growth regulators in micropropagation of woody plants - a review. International Journal Advances Resourch, v.5, n.2, p.2378-2385, 2017. Available from: $<$ http://dx.doi.org/10.21474/IJAR01/3421>. Accessed: Jun. $10,2017$.

von ARNOLD, S. et al. Developmental pathways of somatic embryogenesis. Plant Cell, Tissue and Organ Culture, v.69, p.233-249, 2002. Available from: <https://doi. org/10.1023/A:1015673200621>. Accessed: Jun. 10, 2017.
YASUDA, T. et al. Embryogenic callus induction from Coffea arabica leaf explants by benzyladenine. Plant Cell Physiology, v.26, n.3, p.595-597, 1985. Available from: $<$ https://doi.org/10.1093/ oxfordjournals.pcp.a076946>. Accessed: Jul. 05, 2018.

WILLIAMS, E.G.; MAHESWARAN, G. Somatic embryogenesis: factors influencing coordinated behaviour of cells as an embryogenic group. Annals of Botany, v.57, p.443-462, 1986. Available from: <https://doi.org/10.1093/oxfordjournals.aob. a087127>. Accessed: Jul. 07, 2018. 